\title{
RESTRICTIVE DISTRIBUTION ARRANGEMENTS: ECONOMIC ANALYSIS AND PUBLIC POLICY STANDARDS
}

\author{
LeE E. Preston*
}

Restrictive distribution arrangements result from agreements between suppliers and reseller-buyers of merchandise in which one of the parties or both of them accept limitations on the scope of managerial discretion with respect to certain marketing practices, such as the selection of sales territories, customers, products, or prices. Restrictive arrangements differ greatly in form and substance and in the particular marketing contexts in which they are applied. The purpose of this paper is to develop through economic analysis a framework for assessing the impact of such arrangements, particularly those having to do with customers and territories, on market competition. Within this tramework, we then develop and illustrate a standard for identifying those restrictive arrangements that are compatible with a pro-competitive public policy. ${ }^{1}$

Restrictive distribution arrangements are intermediate forms of vertical market control, between the extremes of no control (independent dealings) and complete control (vertical integration). Neither the economic impact nor the public policy status of such arrangements has been fully articulated, and at the present time vertical marketing relationships of all sorts are undergoing economic, legal, and legislative scrutiny. ${ }^{2}$ Vertical price agreements are, of course, currently regarded as illegal

*A.B. I95x, Vanderbilt University; A.M. 1953, Ph.D. 1957, Harvard University. Associate Professor of Business Administration, University of California, Berkeley.

I should like to acknowledge the substantial contributions of Professor R. M. Buxbaum, University of California Law School, and Edwin H. Epstein, Esq., School of Business Administration, to the development of the ideas in this paper and, particularly, to the location and interpretation of legal materials. Valuable comments have also been received from Dean E. T. Grether and Professors H. O. Stekler and L. P. Bucklin of the Berkeley faculty. Responsibility for interpretations and errors is, of course, my own.

${ }^{1}$ Most general works relating economic analysis to antitrust policy deal with these matters to some extent. Important examples reflecting current thinking include JoE S. Bain, INdustrial Orosnization 327-31, 477-540, 563-78 (1959); Carl Kaysen \& Donald F. Turner, Antitrust Policy 119-27, 142-60 (1959); and Joel B. Dirlam \& A. E. KaHN, FaIr Competition chs. 4, 6 (1954). Recent surveys of the legal issues are contained in Symposium-Antitrust Limits on Distribution Policies and Programs, 26 A.B.A. ANTITrust Section 55-157 ( 1964$)$; Symposium-Vertical Arrangements Under the Antitrust Laws, 22 id. 15-143 (1963); Jordan, Exclusive and Restricted Sales Areas Under the Antitrust Lauss, 9 U.C.L.A.L. REV. III (1962); Travers \& Wright, Restricted Channels of Distribution Under the Sherman Act, 74 Harv. L. Rev. 795 (1962); and Stewart, Antitrust Considerations Involved in Product Distribution, 19 Bus. LAw. 967 (1964).

In addition to the attention directed toward restrictive arrangements themselves, important issues are being raised with respect to mergers, other forms of vertical integration, and diversification of large companies. Cf. Hearings Before the House Select Comm. on Small Business on the Impact Upon Small Business of Dual Distribution and Related Vertical Integration, 88th Cong., 2d Sess. (1964); Hearings Before the Subcomm. on Antitrust and Monopoly of the Senate Comm. on the ludiciary on Economic Concentration, 88th Cong., 2d Sess., pt. I (1964); and Handler \& Robinson, The Snipreme Court vs. Corporate Mergers, Fortune, Jan. I965, pp. 164-78. 
restraints upon trade under section I of the Sherman Act, unless specifically protected by state law. Product restrictions (exclusive dealing and tying) are illegal under section 3 of the Clayton Act where they "substantially lessen competition or tend to create a monopoly ...." In 1948, the Department of Justice issued a policy statement setting forth the view that territorial and customer restrictions were illegal per se, and a number of informal contract modifications and consent judgments were subsequently obtained. ${ }^{3}$ However, several recent court proceedings indicate that this extension of per se doctrine has not been accepted by the judiciary.

\section{I}

\section{Restrictive Arrangements and Competition}

Any restrictive distribution arrangement transfers some of the decision-making authority of one business unit into the control of another. An initial distinction might be drawn between those formally restrictive agreements that do not, in fact, alter the behavior of the controlled unit (or that restrict behavior only with respect to peripheral activities, such as minimum stock levels, display requirements, and so forth), and those which do restrict behavior in some important respect. The former type of agreement (for example, one imposing a modest advertising requirement), which appears to be very common in our economy, may simply represent a codification of existing trade practices without any significant enforcement mechanism or sanctions. Such agreements are restrictive in form but not in substance and may be dismissed from further consideration.

Restrictive marketing arrangements may be adopted both singly and in combination to accomplish particular purposes. Taken individually, the principal types of restrictions and their effects may be summarized as follows: ${ }^{4}$

I. Customer-territorial restrictions limit distributors in their choice of customers or sales areas; they thus reduce the direct competition between distributors of the same line of products, although they may be used to extend market coverage to customers to whom the products would not otherwise be made available. The operation of this type of restrictive arrangement will be considered in detail below.

2. Resale price restrictions limit distributors in their choice of prices, and thus shift competitive efforts into services, location, merchandising technique, or the pricing of nonrestricted products. The impact of resale price maintenance schemes largely depends upon, rather than determines, the strength of interproduct competition; however, resale price restrictions may contribute to the stability of vertical price structures and may importantly affect the number and size of distribution outlets.

3. Product restrictions either compel distributors to carry other of the supplier's

\footnotetext{
${ }^{3}$ Travers \& Wright, stipra note I, at 796-97.

- Throughout this discussion we use the term supplier to refer to the firm on the selling side of the market and distributor to refer to the reseller-buyer. This choice of terminology emphasizes the fact that restrictive arrangements may arise at any vertical market level, e.g., between manufacturers and wholesalers, wholesalers and retailers, industrial distributors and jobbers, and so on.
} 
products (tying) or prohibit them from carrying the products of others (exclusive dealing) as a condition of their being allowed to purchase certain items for resale. Product restrictions thus foreclose particular distributors as routes of market access for competitive products and, as a result, may weaken competition among distributors directly. They may also weaken competition among suppliers by limiting the market choices of distributors and final customers and by creating barriers to the appearance of new products in the market.

Restrictive marketing arrangements of any sort thus limit competition in some respect. However, as we shall illustrate in more detail below, limitations on competitive activity in one direction may strengthen competitive forces in another. The analysis of the over-all competitive impact of any particular pattern of marketing arrangements involves a large number of variables and rests upon a number of crucial distinctions. First, competitive structure, the presence of relatively large numbers of independent decision units on both sides of a market, must be distinguished from competitive behavior, the aggressive pursuit of market opportunities by each individual unit. Restrictive agreements are like mergers in that they can only represent a reduction in the total number of independent decisions to be taken in the market, ceteris paribus. The question for analysis in both cases, however, is whether this departure from competitive structure within one marketing organization is counterbalanced by an increase in the number of marketing organizations and products available in particular markets or in the vigor of competitive behavior.

A second distinction is to be made between interbrand and intrabrand competition. If all branded products were distributed directly by their manufacturers, we would not expect any intrabrand competition to develop in the market. However, when the products of many manufacturers are distributed through independent, and usually multiproduct, distribution outlets, the prices of individual products become elements in the over-all competitive strategy of these firms. Their "enterprise competition"5 involves the sale of complex assortments of goods and services and the attraction and retention of customer patronage over time. Thus, intrabrand competition arises because of differences in the cost and demand conditions facing various distributors and their differing responses to market opportunities. Restrictive arrangements with respect to any product limit, and may completely eliminate, the use of that product as a vehicle of enterprise competition among distributors. However, whether this has any perceptible effect on the vigor or character of competition over-all will depend upon many other factors. Among the most important of these are the presence of alternative brands (and the strength of interbrand competition) and the variety and importance of service, location, and other nonprice elements of competitive strategy.

A closely related matter is the interaction between horizontal and vertical market relationships. The present state of economic analysis does not, in general,

\footnotetext{
'This term was coined by Dean E. T. Grether.
} 
permit us to specify the impact of changes at one of several vertically related market levels upon structure and behavior at another. Even were a fairly detailed analysis possible, there is far from universal agreement as to the public policy criteria to be applied in choosing among several possible multi-market patterns of competitive forces. In general, there is some presumption that competitiveness in "final" markets is the primary public policy consideration, but this criterion is not fully satisfactory because (a) the identification of any one market as "final" becomes somewhat ambiguous with respect to products other than nondurable consumer goods and (b) some reduction in competition in final markets (e.g., limitation on intrabrand competition) may be associated with the maintenance or increase of competitive alternatives in intermediate markets.

Finally, there is a distinction to be drawn between the balance of competitive forces throughout a broad market and the strength or weakness of bargaining positions of particular buyers vis-à-vis particular sellers. For example, when either party to a transaction has come to rely upon the other for more than the normal provision of merchandise and service available elsewhere in the market, the dependent party's bargaining position becomes weakened, and the dominant party may attain a power of coercion over this particular trading partner in no way paralleled in its dealings with other enterprises. The illegality of contractually exercised coercive power, quite apart from any association with market-wide monopoly, has been recently affirmed in Lessig $v$. Tidewater Oil Co. ${ }^{6}$ and Simpson v. Union Oil Co. In both cases, suppliers were using their power over dealers to force the acceptance of restrictive marketing arrangements (tying in the first instance, consignment selling in the second). In neither case was it shown that competition in final product markets-oil and gasoline-was directly affected by the arrangements.

II

\section{Noncolluusive Restrictions on Sales Territories and Customers}

This paper focuses primarily on the economic impact and public policy status of restrictive arrangements involving the limitations of distributors in their selection of sales territories or customers. We omit detailed consideration of resale price restrictions, except as they may be involved in our primary topic, because they have been the subject of extensive analysis for some thirty years and their legal status as per se violations, except where specifically exempted by state law, seems reasonably secure and appropriate. ${ }^{8}$ Product restrictions in the form of tying contracts are

\footnotetext{
${ }^{8} 327$ F.2d 459 (9th Cir.), cert. denied, 377 U.S. 993 (I964).

377 U.S. $13(1964)$.

8 The economics profession, with very few exceptions, has been generally critical even of legalized resale price maintenance. The typical argument is well summarized by Bain, who recommends the repeal of state fair trade laws and federal enabling legislation. Bars, op. cit. supra note 1 , at $565-67$, 627; a similar suggestion is made by KAYSEN \& TURNER, op. cit. supra note 1 , at 212-13. The outstanding economist proponent of fair trade, as a source of countervailing (or perhaps only equalizing) power for small business, has been Walter B. Adams. Cf. Adams, Resale Price Maintenance: Fact and
} 
covered in another contribution to this symposium; exclusive dealing restrictions, which are frequently associated with customer-territorial restrictions, require some specific comment below. In general, the several types of restrictions may be used both jointly and as alternative means of accomplishing the same managerial objective.

Territorial and other customer restrictions may be analyzed together because they have the common effect of limiting the distributor in his choice of customers, according to their trade designation, size, location, or other characteristics. Territorial restrictions, the most familiar form of simple franchise, have given rise to a number of significant recent court cases, and the territorial feature is emphasized in much of this discussion; however, the argument should be read as equally applicable to the limitation of choice of customers on any other basis.

The focus of this symposium on single-firm conduct excludes a detailed consideration of the use of restrictive distribution arrangements in a context of horizontal collusion or conscious parallel action. It might, however, be argued that all restrictive arrangements of any significance contain, at least by implication, a collusive aspect. Distributors who are parties to such agreements are generally aware that parallel arrangements are being made with their potential competitors; thus, the granting of an exclusive franchise to a distributor is an implicitly collusive quid pro quo for his acceptance of a limited territorial or customer outreach. This is, in essence, the crux of the argument for the extension of per se standards of illegality to cover restrictive arrangements of all types. We would distinguish here, however, between (I) a horizontal conspiracy implemented through a vertical agreement and (2) a single firm's (e.g., a supplier's) development and implementation of a system of vertical agreements for the accomplishment of its own marketing goals. Current public policy does not differentiate the two cases in so far as price agreements are concerned. ${ }^{9}$ However, in his concurrence in White Motor, Mr. Justice Brennan explicitly distinguished "two traditionally outlawed forms of restraint-horizontal market division and resale price maintenance"-from "territorial restraints ... imposed upon unwilling distributors by the manufacturer to serve exclusively his own interest."10 The latter were, in his view, presumably legal.

Fancy, 64 YALE L.J. 967 (1955). Other recent contributions analyzing the impact of fair trade practices in a managerial context are Telser, Why Should Manufacturers Want Fair Trade?, 3 J. LAw \& Econ. 86 (I960); Gould \& Preston, A Model of Resale Price Maintenance, 32 Economicn 302 (1965).

${ }^{\circ}$ KAYSEN \& TuRnER, op. cit. supra note $\mathrm{I}$, set forth some explicit standards for the appraisal of per se rules and accept the validity of this approach with respect to price-fixing, atlhough not with respect to tying contracts or exclusive dealing. They do not deal specifically with customer-territorial restrictions. Turner, writing alone, offers purpose and power to restrain competition as a test for identifying per se illegal tie-in arrangements, although he leaves some classes of arrangements for case-by-case analysis. Turner, The Validity of Tying Arrangements Under the Antitrust Laws, 72 Harv. L. Rev. 50, 62 (1958). The validity of per se rules even in the price-fixing context has been strongly challenged by the economic analysis of Almarin Phillips. Sec his Market Structure, Oroanization and Performance chs. io-i i (I962).

${ }^{10}$ White Motor Co. v. United States, 372 U.S. $253,266-67$ (1963). 
Absent horizontal conspiracy, restrictive distribution arrangements arise because distributors, left to their own devices, do not behave as a supplier would wish and, as a result, the goals of the supplier are not realized through the independent action of competitive distributors in the market.

The motives of a supplier in introducing restrictive marketing arrangements may be many and varied, but the following are frequently cited in the literature and court proceedings: $:^{11}$

r. To obtain market access-Distributors may be unwilling to handle a supplier's product unless they are partially insulated against intrabrand competition; thus, distribution outlets in any one submarket may be obtainable only if restrictions are imposed on the activities of potential competitors. This consideration is particularly significant when the distributors are required, either by economic considerations or trade practices, to deal exclusively in the supplier's product. ${ }^{12}$

2. To increase product exposure-If final market sales are strongly affected by the number and convenience of distribution outlets carrying the product, then the supplier may wish to limit each outlet to minimum feasible size and increase the number of outlets to a maximum.

3. To increase total distributors' sales effort-Any particular amount or quality of sales effort might be spread widely through a market or concentrated on narrowly defined customer groups. Customer-territorial restrictions are frequently designed to motivate distributors to increase their depth coverage of narrowly defined markets rather than "skimming" choice customers over a wider area. ${ }^{13}$

4. To determine quality and character of distributor service and to achieve other merchandising ends-In order to engage in brand name promotional activity on a continuing market-wide scale, a supplier may wish to obtain both specific character and quality and a considerable degree of uniformity in the operations of its distributors, including not only pre-sales service but also post-sales and replacement responsibility, ancillary merchandising activity (e.g., local advertising), and so forth. Restriction of customer groups, territorial or otherwise, to specific distributors may contribute to these goals, either because the distributors independently accept the

\footnotetext{
${ }^{11}$ It is sometimes argued that many restrictive arrangements are actually in the distributors' best interests and that the supplier simply develops and enforces them "for the distributors' own good." It may indeed be true that some suppliers, through the ability to study the entire market and to consider a wide range of managerial alternatives, are peculiarly well situated to advise, assist, and even persuade distributors to follow more profitable operating procedures. However, it presupposes both an undue omniscience on the part of suppliers and an undue denseness on the part of distributors to argue that the latter must be continually compelled to follow courses of action in their own best interests.

${ }^{12}$ A special case of the "market access" motive involves new products, for which the territorial monopoly may be an important stimulant to investment in promotional activity and risk-taking on the part of distributors. Use of restrictive arrangements with respect to new products would not explain their persistence over time; however, the new product case is a powerful argument against per se prohibition of all customer-territorial restrictions, as the courts have apparently recognized. Cf. United States v. Jerrold Electronics Corp., 187 F. Supp. 545 (E.D. Pa. 1960), aff'd, 365 U.S. 567 (196r). Compare Jerrold Electronics Corp. v. Wescoast Broadcasting Co., 341 F.2d 653 (9th Cir. 1965).

${ }^{13}$ This and the following point are particularly emphasized by Jordan, supra note I, at I13-22.
} 
appropriate norms and standards or because they can be persuaded to do so in return for competitive insulation.

A large number of more specific considerations might be listed, but the foregoing include the principal points in the literature and already involve some duplication. It may be relevant, however, to ask why a supplier would prefer a restrictive arrangement to the complete control of a distribution outlet through vertical integration. Three characteristics of distributive activity are of paramount importance in this connection. ${ }^{14}$ First, distribution is a relatively low-profit activity; if a supplier can obtain the desired degree of control without assuming full investment responsibility, he may be able to employ his capital more profitably elsewhere. Second, distribution is typically a multiproduct activity, with the product mix of distributors substantially different from that of any one supplier; vertical integration under these circumstances involves a substantial broadening of a supplier's product responsibility as well as his functional role. ${ }^{15}$ Finally, the local managerial problems and personal service content of distribution discourage suppliers from integrating forward when other alternatives are available. ${ }^{16}$

\section{III}

\section{A Model of Customer-Territorial Restrictions}

The courts have clearly held that at the present time restrictive distribution practices are not per se illegal in the United States under existing statutes, and we have cited above a number of legitimate business considerations that might motivate a supplier of merchandise to introduce restrictive arrangements among his distributors. It remains, however, to inquire whether or not the introduction of such arrangements will necessarily, or even probably, result in some reduction in the strength of competitive forces in the economy. In order to examine this question, we construct an abstract model of a spatial market and examine the impact of restrictive practices on this market under certain specified conditions. From the results of this analysis we are able to suggest some generalizations that might serve to identify instances of restrictive distribution permissible under a pro-competitive public policy. ${ }^{17}$

\footnotetext{
${ }^{14}$ For the most recent general survey of the economics of distribution in the United States, see Reavis Cox, Distribution in a High-Level Economy (1965).

${ }^{15}$ The principal form of retailing in which manufacturers exercise a dominant decision-making role, including formal vertical integration in some instances, is gasoline marketing; the second most conspicuous example is automobile dealerships. In both instances, the principal product of the supplier is also the principal product of the retailer. The former do not, in general, involve customer restrictions other than those arising entirely out of physical location, but the latter have involved very explieit territorial restraints in the past and continue to do so in some cases. Cf. B. P. Pashigian, The Distribution op AUtomobiLes ch. 2 (196r); Travers \& Wright, supra note I, and references therein.

${ }^{10}$ Similar points are made by Travers \& Wright, supra note $I$, at 834 , and Stewart, supra note $x$, at 38-46.

17 To interpret the model as a case for customer restrictions by industry, read cach "location" as a different class of customer, with the proximity of locations reflecting the similarity of product require-
} 
As the framework for our model, assume the existence of a set of potential market locations evenly distributed along a line in space. Potential customers of different sizes (size measured by potential volume of purchases) are distributed evenly along the line, and the size distribution of customers is the same at each location. We analyze the problem of a single supplier and its associated single-product distributors in marketing to these potential customers on the assumption that both the final market price and the distributor price are fixed and uniform over all quantities and all customers.

Assume next that the establishment of a distributorship involves one particular amount of capital investment and that the criterion used by distributors in making this investment is the achievement of a specific minimum net rate of return. Assume also that the distributors have three types of variable costs:

I. cost of merchandise purchased for resale, which is constant per product unit;

2. cost of customer contact, which is constant per unit of distance between distributor and customer; and

3. cost of transactions, which is constant per customer.

Under these cost conditions, two propositions hold:

I. at any given location, the profitability of distributor sales to any particular customer will be directly proportional to customer size, ${ }^{18}$ and

2. for customers of any given size, the profitability of distributor sales will be inversely proportional to the distance between customer and distributor. ${ }^{19}$

We would expect a distributor at any particular location to contact potential customers at his own location beginning with the largest and continuing down the size categories until he reached those customers for whom the revenue-cost margin just equalled the cost of making the transaction. Similarly, we would expect the distributor to extend his market coverage to customers at other locations to such a point that the rising contact costs just equalled the net profit (gross margin less transaction cost) attainable. These two criteria define the intensive and extensive margins of market exploitation for the distributor, and his submarket may be described as including all potential customers for whom the revenue-cost margin

ments and distribution channels among classes. The entire argument could also be restated for a single distributor dealing with a group of suppliers; under appropriate cost and demand assumptions, each supplier may obtain the same profit whether he distributes through one or many outlets, but the distributor may benefit from holding an exclusive franchise, even if the result is only to attract customers to other merchandise.

${ }^{18}$ The larger the customer, the greater is the aggregate difference between total receipts from the sale and total cost of merchandise; deduct from this aggregate the lump-sum cost of making the transaction to obtain the net profit per customer, which will be directly proportional to the size of the sale.

${ }^{10}$ Note that our model includes no source of diseconomies of scale other than the rising contact costs associated with customers in more distant locations. This assumption reflects the general observation that there is a significant amount of permanent excess capacity in most distribution activities. Cf. Cox, op. cit. supra note 14 , ch. 12 . 
equals or exceeds the sum of the contact and transaction costs. A diagrammatic representation of such a submarket, showing both spatial outreach and customer depth at each spatial location, is presented in figure one. ${ }^{20}$

\section{FIGURE I}

Development of a Distributor Submarket by Spatial Outreach and Customer Depty

For a distributor at location $\mathrm{H}$, the unit price-cost margin, contact costs over space, and transactions cost determine the spatial limits of the submarket (locations $A$ and $O$, where only customers of size 100 are serviced) and the depth in terms of customer size (size 25 at location $\mathrm{H}$ ).

We have assumed that the investment requirements per distributor are fixed regardless of location, number of customers reached, or volume. If the profits attainable from one optimal-sized submarket are greater than would be available from an equivalent amount of capital employed elsewhere, then, with unrestricted entry, we would expect additional distributors to appear. Each of them would select a geographic location such that his spatial outreach did not overlap with any existing distributor, and the pattern of market coverage that would result is illustrated in figure two. Note that a large number of potential customers may not be reached by any distributor under this pattern of coverage.

If the profits obtained from these optimal-sized distributorships were exactly equal

${ }^{20}$ The model developed here is the simplest possible one that will illustrate the argument. The spatial dimension of the market is made linear, not curcular, as in the more usual example, in order to make it possible to illustrate the concept of market "depth" while keeping the diagram to two dimensions. The triangular limits of the submarket may be interpreted as a vertical cross-section of a cone, in two-dimensional space. When the spatial market is entirely filled with distributors, as in figure three below, the spatial (horizontal) boundaries of each submarket would be hexagonal, as Losch has shown.

The economic literature on "line" and other spatial market models is very large. The single most important theoretical work is A. Losch, THE Economics of Locntion (1954; first published in German in 1940). Essential early references are E. H. Chamberlin, The Theory of Monopolistic Competition Appendices A and C (6th ed. 1950); and Hotelling, Stability in Competition, 39 Econ. J. $4^{1}$ (1929). The standard general text on spatial economic relationships is E. M. Hoover, THE Location of Economic Actuviry (r948).

A model fundamentally similar to but much more elaborate than that presented in the text is contained in Mills \& Lav, A Model of Market Areas with Free Entry, 72 J. Pou. Econ. 277 (1964). This model demonstrates in a more general framework that free entry in a spatial market need not 'result in the filling of all market spaces nor in the most efficient use of production and transportation resources. 
FIGURE 2

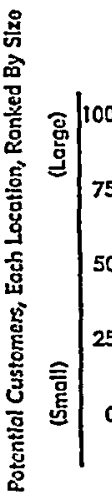

Market Occupancy by Noncompetittve Distributors

Market Locotions $A-B-C-D-E-F-G-H-I-J-K-L-M-N-O-P-Q-R-S-T-U-V-W-X-Y-Z-A^{\prime}-B^{\prime}-C^{\prime}$

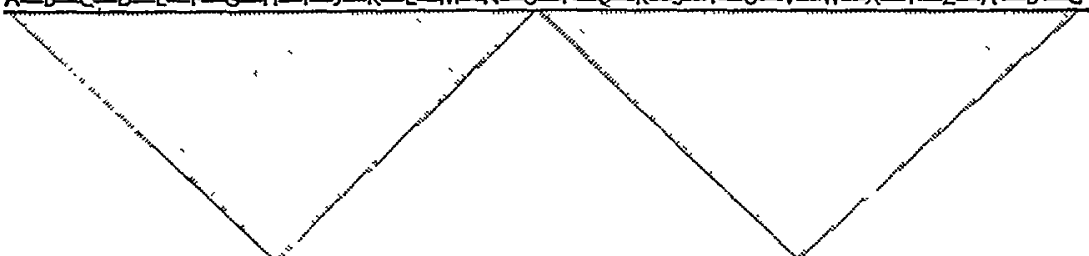

Potentiol Customers Not Reoched

to those available from similar investments elsewhere, no additional distributors would be tempted to enter the market, nor could the supplier induce such entry without offering to increase distributor profits through distributor price reduction, subsidy, or other means. However, if the optimal-sized distributors are earning better than normal profits, additional distributors may wish to enter the market. The supplier will also desire such distributors to enter because they can provide additional market coverage. However, wherever such additional distributorships are established, they will include in their submarkets some of the customers already served by the optimal-sized outlets. Thus, the attainment of increased market coverage-desired by the supplier (and by the potential entering distributors)involves the development of interdistributor (intrabrand) competition and a reduction in the size and profitability of distributorships.

Although new distributors might for a time take customers from established firms simply on the basis of convenience and without altering the basic price and cost relationships of the industry, eventually the encroaching outlets and the established outlets would begin to compete directly for customers. This competition might take the form of price reductions, either selective or across-the-board, or additional expenditures on selling costs. Either form of competition has the same effect upon distributor profits, reducing them below the level they would have reached if the same sales volume per distributor were attained without competition. If the competitive price reductions are market-wide, they will reduce the depth coverage of the market because they lower the profits available from transactions with smaller customers. ${ }^{21}$ Even if the reductions are only selective, or if selective selling cost increases are used instead, the profitability of every competitive distributor in the sale of any given volume of product is reduced. This has an

\footnotetext{
1 We might term this the "perfect competition" result. It implies that price is the only element of competition among distributors, and that final market prices fall until each distributor is earning only normal profits. The spatial market would be full of distributors, but the depth of their coverage would be reduced. The final numbers-spatial-depth outcome would depend upon the investment requirement and cost structure.
} 
important implication for the supplier. It means-and here is the point-that with direct competition among distributors, their number and size may stabilize so as to provide a lower level of market coverage than a restrictive distribution arrangement would permit; thus, the total sales of the supplier's product in the final market may be reduced under competitive, as compared to restricted, distribution arrangements.

For this reason alone, in a market corresponding to our simple model, a supplier would be well advised to restrict the customers and territories served by his dealers so that they might obtain normal profits on their operations under conditions that result in levels of market coverage, selling price, and sales quantity that maximize his own profits. Since competition will govern the returns of distributors in any event, the supplier has reason to prefer (and the distributors no reason to disprefer) that normal profits be obtained by a maximum number of distributors, resulting in a maximum total sales volume, given the price. ${ }^{22}$ The resulting pattern of distributor market occupancy is pictured in figure three.

Two conceptual simplifications involved in this model deserve brief comment. First, we have discussed the introduction of distributors into the market as if it occurred gradually over some time period. From the viewpoint of a decisionmaking supplier, the situation might be better described in terms of a forecast of possible market developments. Second, we have omitted any consideration of the existence of other suppliers and their associated distributors in the market. Although the number and strength of such competitors raises plenty of management problems, their presence or absence has no great impact on our argument. Either $(a)$ there are no direct competitors, and the potential customers will simply spend their money on other products or increase their savings if the supplier's product is not made available to them, or (b) there are direct competitors such that any sales of this supplier's product are matched by lost sales of another's-or else some combination of (a) and (b) prevails. Whatever the circumstances, if the customers are assumed to have any judgment or taste in the matter, their selection of the particular supplier's product reflects a preference for it over the available alternatives, including the

\footnotetext{
${ }^{32}$ Criteria for the selection of an optimal final market price, total quantity, and number of distributorships by the supplier may be briefly indicated. Larger numbers of distributorships are associated with higher levels of market demand at all final prices; and every size (and, therefore, total number) of distributorship(s) is associated with a particular gross distributor's margin per sales unit, determined by the distributor's capital requirement and minimum rate of return. The supplier would obtain his own net market demand schedules by subtracting the relevant minimum unit margin from each possible final demand schedule, determined by the number of distributors. The optimal number of distributors from the supplier's viewpoint would be that resulting in the highest of these net demand schedules, and the supplier would select the price-quantity combination on this schedule best calculated to maximize his own profits over the market period. A supplier with significant monopoly power in the final market may even increase the number of distributors beyond that compatible with the maintenance of normal profits, either by (a) subsidization, so long as gross profits from increased coverage are greater than subsidy costs, or (b) raising final market price and distributor's unit margin through resale price maintenance. For a diagrammatic development of this point, under slightly different cost conditions from those assumed here, see Gould \& Preston, supra note 8.
} 
FIGURE $_{3}$

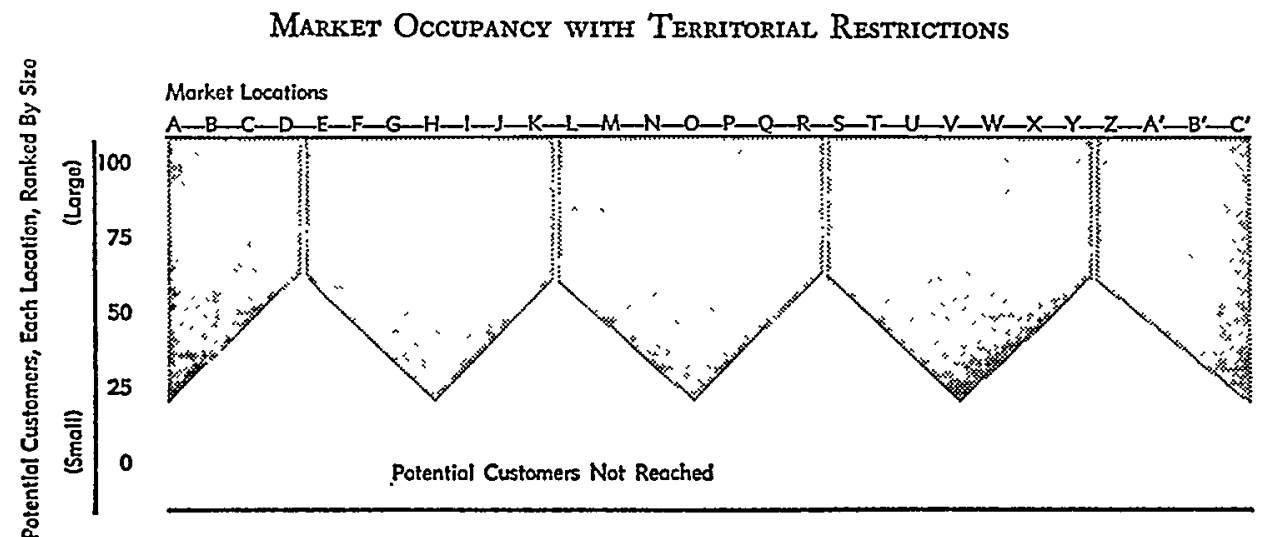

Distributors are located at $A, H, O, V, C^{\prime}$, etc.

alternative of saving their money. Thus, there is every reason to believe that the customer population is not directly harmed, and quite possibly benefited, by the establishment of a maximum number of viable distributorships. Whether the establishment of additional distributorships results in an over-commitment of resources to distributive activity in the economy, or in an excessive turnover of management and capital due to bankruptcies, are questions we do not investigate here.

Let us now summarize some principal features of the application of customerterritorial restrictions within this simple model:

I. Referring back to our earlier list of motivations for restrictive distribution, the example presented in our model covers the first two motivations (obtaining market access and increasing exposure) exactly. It also has implications, as noted below, for the third and fourth (increasing sales effort and controlling service quality).

2. The supplier obtains the best possible coverage of the market, given the structure of distribution costs, and is thus in a position to obtain the best available over-all price-quantity combinations. If competition among suppliers (i.e., among brands) is strong in the final market, then the best available alternative may simply be competitive returns for the supplier himself. On the other hand, if interbrand competition is weak, the supplier may be able to establish a higher final market price and, deducting normal profits for distributors, obtain an abnormal profit for himself.

3. The distributors receive only normal profits and are as small and numerous as possible consistent with the price and margin established by the supplier. There is no inconsistency between this result, which arises directly out of the general argument of our model that restrictive arrangements increase the number of distributors over what it otherwise would be, and the superficial effect of restrictions in limiting or reducing the number of distributors. The difference lies in the character of the 
distributive outlets, their costs, locations, and functions. Our analysis indicates that restrictive arrangements will be used to increase the number of outlets of a specified type or quality; the preservation of such outlets may, of course, require the elimination of potentially competitive outlets with other operating and service characteristics.

4. The distributors can be made better off only if the supplier is made worse off and the restrictions are maintained. The removal of restrictions may allow the size and activity of distributors to change but not their profitability. However, if restrictions are maintained but prices raised or markets widened, then distributors may gain while the supplier loses. (Skillful bargaining may allow the distributors to obtain some of these gains as their reward for cooperating with the supplier's plans, even though they could not do as well acting independently.)

5. The welfare of final customers is not clearly affected by the selection of restrictive over nonrestrictive distribution arrangements in this model. If competition took the form of selling expenses or free services, these might benefit particular customers, annoy others, or be of no importance. If competition took the form of price reductions, either general or selective, those customers receiving the reductions would benefit. However, whatever the form of competition, there would be some reduction in the coverage of the market as compared to that provided by restricted distribution, because of the reduction in number of distributors if for no other reason. Thus, the gains to favored customers must be measured against the loss of market alternatives to others willing to pay but shifted beyond the breakeven margins by the change in distributor costs. The extension of service to these customers contributes to their own welfare as well as to supplier profits; even if these customers are reached by other suppliers of similar products, the provision of an additional market alternative cannot be dismissed as negligible in all cases.

6. Note that in this model the supplier can do nothing to extend the intensive market margin (the depth of coverage) of distributors directly. However, distributors whose range of territorial outreach is sharply limited may find it possible to extend service to extra-marginal customers within their own sales territories on a price-discrimination or reduced-cost basis (which raises some other legal problems, of course). These possibilities are not easily included in our simple model, but they are probably real enough in actual markets to constitute an important side effect of restricted distribution arrangements. ${ }^{23}$

In our abstract model, the competitive structure of distribution limits dis-

\footnotetext{
${ }^{23}$ The manipulation of our model has been greatly simplified by the assumption that only a single amount of investment was required to establish a distributorship, regardless of capacity, location, and so on. This assumption is probably acceptable as a reflection of some minimum level of distributive capacity, and even of capital requirements within each of several size classes of distributors. However, if a distributor in our model can select some level of investment lower than that required to reach an optimal-sized market, he may choose to do so. Such a reduction will raise the rate of return represented by any particular aggregate of dollar profits. The reduction may or may not reduce the distributor's ability to cover his own territorial market in depth; if it does, then the supplier may be motivated to introduce additional stimuli-aids, subsidies, or quotas- to maintain depth coverage.
} 
tributors' profits to normal levels, with or without territorial restrictions, and thus the distributors are assumed to be indifferent as between independence and restricted arrangements. In fact, of course, they may have strong preferences between the two and will almost certainly have preferences as to the particular forms that restrictions may take. Not only are there the extreme possibilities of a monopolistic price-fixing conspiracy among the distributors on the one hand and the reduction of profits below normal levels by a coercive supplier on the other, there are myriad variants in between. If "the greatest of all monopoly profits is a quiet life," the closed territory distributor may value his position for that reason alone. Further, in the process of establishing and maintaining an optimal system of territorial distribution, a supplier may provide extensive managerial and investment assistance, advertising support, and so forth. These forms of aid may be provided at little or no direct cost to the distributor, both because they are undertaken by the supplier in the pursuit of profits from complete market coverage and because their costs, per distributor, are in fact very low for the supplier as a result of scale economies.

\section{IV}

\section{A Policy Standard for Restrictive ArRangements}

In the language of the Addyston Pipe case, restrictive distribution arrangements are reasonable, and therefore permissible, under the Sherman Act when "the restraint is such only as to afford a fair protection to the interests of the party in favour of whom it is given, and not so large as to interfere with the interests of the public."24 The analysis of customer-territorial restrictions developed from our model enables us to propose that this criterion be specified more precisely in this two-part test:

Restrictive arrangements imposed upon distributors individually by a supplier are permissible when-

I. they make possible, with no direct reduction in the availability of products of other suppliers, a level of market coverage for the supplier's product substantially greater than could be attained with overlapping distributorships, and

2. they do not result in distributor or supplier profits substantially different from "normal" levels for the risk, skill, and capital involved.

The first part of this test examines the impact of the arrangement on the availability of product and outlet alternatives in the final market and the importance of competitive costs. The second discriminates between the permissible cases and those involving horizontal collusion among distributors, coercion of captive distributors by suppliers, and vertical restrictions supporting a supply monopoly. The key word

\footnotetext{
"United States v. Addyston Pipe \& Steel Co., 85 Fed. 27 I, 282 (6th Cir. I898), quoting Chief Justice Tindal, in Horner v. Graves, 7 Bing. 735, 743, I3I Eng. Rep. 284, 287 (C.P. I83I).
} 
in the second part of the test is result; it is not enough that restrictive practices may occur in a context of abnormal profits-there must be some cause-effect relationship between the two.

The simplest case covered by our proposed test-in which neither distributors nor supplier earns abnormal profits but the restrictive arrangement permits extensive market coverage and widens the range of competitive alternatives-would seem fanciful were it not apparently illustrated in a number of recent court proceedings, to which we shall refer specifically below. But what about the more difficult case in which the first criterion is met and there is no evidence of excessive profits or horizontal conspiracy among distributors but supplier profits are abnormally high? The answer depends upon whether or not the supplier profits can be traced to the restrictive arrangement. If the arrangement centers on price maintenance, the supposition of a cause-effect relationship is quite strong. It is possible, but experience suggests very unlikely, that distributor prices are being held up while supplier prices and profits are being held down. On the contrary, one of the classic motives for resale price control is to insulate the supplier from the forces of price competition among distributors and, indeed, to enlist them as partners in the pursuit of monopoly profits.

With customer-territorial restrictions considered alone, however, the supposition seems to run the other way. Their effects upon the level of final market price are, at most, indirect and may run in either direction. They do not contribute to the weakening of the interbrand competition in final markets or serve as barriers to entry. On the contrary, they assure a prospective competitor that in any submarket he will have only one, rather than many, distributors of a particular supplier's product to contend with.

Our test does not specifically cover a particular type of restrictive arrangement that we have omitted from the body of our analysis, namely, the reservation of certain territorial or, more commonly, customer groups (e.g., governmental units) for direct service by the supplier. This pattern of distribution has traditionally given rise to a considerable amount of complaint among the distributors affected. ${ }^{25}$ Such practices may indeed reduce the profits of distributors below what they otherwise would be, and the post hoc reservation of new customers initially developed by the distributors may constitute illegitimate coercion or interference. However, where post hoc coercion is not involved, such reservations do not appear to have an anticompetitive effect. Given that the entire flow of merchandise originates with the supplier, his reservation of some part of that flow for his own use, including use in sales to selected final users, cannot be shown to have any necessary impact, either positive or negative, on the over-all strength of competitive forces.

The case against customer-territorial restrictions where suppliers are profitable

${ }^{85} \mathrm{Cf}$. Hearings Before the House Select Comm. on Small Business on the Impact Upon Small Business of Dual Distribution and Related Vertical Integration, 88th Cong., 2d Sess. (1964). 
or relatively large ${ }^{26}$ appears to rest on an association between these restrictions and parallel limitations on the range of products marketed by a distributor, i.e., exclusive dealing. Exclusive dealing is, indeed, the obverse of customer-territorial restriction, and there may well be cases in which a supplier desires not primarily the increased market coverage posited in our model but rather the elimination of interbrand competition within individual distribution outlets. The territorial restriction is then the distributor's quid pro quo; if he is to give up the distribution of competitive products, he must be guaranteed a market in which intrabrand competition is eliminated. In arranging such distributorships, the supplier would, of course, be motivated to obtain maximum market coverage, as suggested by our model; however, the analysis of the operation of such a distribution system would include its exclusive feature as well. This feature may well constitute a barrier to the development of new competition, and thus may contribute to the achievement of noncompetitive price and profit levels for both distributors and suppliers. If so, the exclusive dealing aspects of the arrangement would be, and should be, illegal under section 3 of the Clayton Act. ${ }^{27}$

The test of the permissiveness of restrictive arrangements set forth above is not intended as an across-the-board challenge of the per se rule against vertical pricefixing nor of the Clayton Act's restraints on exclusive dealing and tying. It is, however, intended to suggest that the impact of particular restrictive practices depends upon their context, including their association with other practices, and thus that an extension of per se rules in this area is at present unjustified. More explicit regulations in the trade practices field might arise from either the simplistic extension of per se illegality to all restrictive practices or the identification of particular characteristics of firms and/or markets for which particular practices would be permitted or prohibited. Possible characteristics cited include (a) the profitability and market share of the supplier firm and $(b)$ the number and strength of alternative suppliers in intermediate and final markets. ${ }^{28}$ The preceding analysis has

\footnotetext{
${ }^{20}$ For example, Travers \& Wright, supra note $x$, at $832-34$.

${ }^{27}$ Under the Standard Stations doctrine, the legal status of exclusive dealing arrangements appears to turn entirely on "proof that competition has been foreclosed in a substantial share of the line of commerce affected." Standard Oil Co. v. United States, 337 U.S. 293, 314 (1949). The Court has subsequently pointed out, however, that application of this doctrine involves three separable steps: (I) determination of the "line of commerce," (2) demonstration of actual or "threatened foreclosure of competition [in relation to] the market affected," and (3) demonstration that "the competition foreclosed . . . constitute[s] a substantial share of the relevant market." Tampa Elec. Co. v. Nashville Coal Co., 365 U.S. $320,327,328$ (I961). For an analysis of the current status of this doctrine, see Bok, The Tampa Electric Case and the Problem of Exclusive Arrangements Under the Clayton Act, 196I Sup. CT. REv. 267.

2* Travers \& Wright, supra note 1 . An additional characteristic sometimes mentioned is the strength and form of sanctions included in the restrictive arrangements. Harsh sanctions, such as revocations of franchise and fines (either direct or in the form of a profit pass-through), would render agreements invalid, but those containing only weak penalties or admonitions would be permitted. The distinction being drawn appears to be that between arrangements that are restrictive in substance and those that are only restrictive in form. This criterion may be useful for rejecting particular arrangements as not requiring serious analysis (because of no effect); however, it is of no use in diseriminating among cases in which substantive restraints are, in fact, involved.
} 
already dealt, at least by inference, with the relevance of the first group of characteristics; we now turn briefly to the second.

In considering the number and strength of alternative suppliers, brands, or products in affected markets as a determinant of the permissibility of restrictive practices, we would distinguish sharply between the criteria applicable to exclusive dealing or resale price maintenance, on the one hand, and customer-territorial restrictions on the other. The presence of few alternatives in a product-line or market may indicate that exclusive dealing arrangements have, in fact, already worked to foreclose channels of market access. At a minimum, a pro-competitive public policy would suggest that no barriers be placed on the introduction of new products or brands into small-numbers markets. Similarly, the power to raise prices through resale price maintenance is heavily dependent upon the strength of competitive alternatives; thus, where these alternatives are weak, the possibility of pernicious effects from price control are strong, and vice versa. By contrast, our analysis of customer-territorial restrictions indicates that they may be used to extend market coverage and thereby increase the range of competitive alternatives available to particular customers. Such an increase may have its greatest value, from a public policy viewpoint, in those markets where the number of competitive alternatives is very small. This point is frequently recognized with respect to the introduction of new products and constitutes a kind of "infant industry" defense of business practices otherwise proscribed. However, it is equally if not more important in the maintenance of competitive strength for existing products. It may be argued that the mere presence of customer-territorial restrictions reduces the flexibility and adaptability of marketing organizations over time and thus contributes to the perpetuation of dominant market positions (and excessive profits) for particular suppliers or distributors. However, any such vague theorizing must be countered by the (equally vague) consideration of potential cost reductions, service improvements, and dealer responsibility and continuity attainable within stable organizational structures.

There is one final point to be made in defense of certain restrictive distribution arrangements. With a few exceptions, there is, at present, no explicit public policy commitment for the freezing of particular patterns of marketing organization or particular divisions of aggregate profits among raw materials producers, manufacturers, merchandisers, and distributors and their various sources of labor and materials. Because there is no general public policy stance in opposition to organizational changes brought about by vertical integration (including bona fide agency agreements) not involving mergers, the prohibition of certain interfirm arrangements may stimulate the absorption of market relationships into intrafirm management decisions through integration. ${ }^{29}$ Integration is more likely when a distributor can operate efficiently while marketing the products of a single supplier, and this same market characteristic is promotive of exclusive dealing and restrictive

\footnotetext{
39 Almarin Phillips, Market Structure, Organization and Performance chs, to-il (1962).
} 
customer arrangements (but not particularly of price restrictions, it should be noted). If the only serious argument against noncollusive marketing restraints is that they may have a general tendency to rigidify market relationships and reduce competitive Alexibility over the long term, the substitution of vertically integrated structures does not appear to be a desirable alternative. On the other hand, the prohibition of changes in vertical marketing patterns might introduce an inflexibility into the system equal to or greater than that associated with vertical integration itself. Thus, the continued permissibility of limited restraints, always subject to examination as a result of complaints by injured parties or the finding of public authorities, may make possible the most desirable attainable combination of competitive marketing structure and behavior.

\section{V}

\section{The Standard Applied}

The final task of this paper is to illustrate the applicability of the principles set forth above to some specific marketing situations. For this purpose we have selected four recent court cases in which question was raised as to the legality of restrictive distribution arrangements. This attempt at application is somewhat dangerous, since neither time nor available data have permitted an exhaustive study of the facts of particular cases, nor can this brief presentation include a detailed statement of all necessary qualifications. However, we choose to incur the risk because application will clarify the intended limits of the public policy standard set forth above and thus facilitate its critical appraisal.

\section{A. The White Motor Case $^{30}$}

The Department of Justice brought suit against the White Motor Co., a manufacturer of trucks, contending that its franchise agreements constituted per se restraints of trade under the Sherman Act. White franchisees were restricted as to their sales areas, customers, and resale prices; the restrictions applied at both an intermediate "distributor" level and a subsequent "dealer" level of the marketing organization. The Department asked, and the district court granted, summary judgment that the arrangement was illegal. The Supreme Court, however, held that the summary judgment was not justified, except in regard to price fixing, because

this is the first case involving a territorial restriction in a vertical arrangement; and we know too little of the actual impact of both that restriction and the one respecting customers to reach a conclusion on the bare bones of the documentary evidence before us. ${ }^{31}$

${ }^{80}$ White Motor Co. v. United States, 372 U.S. 253 (1963), reversing 194 F. Supp. 562 (N.D. Ohio 1963). The lower court proceeding in this case is briefly summarized in Travers \& Wright, stpra note $\mathrm{x}$, at 797-801. An important comment supporting the view presented in the text is to be found in Handler, Recent Antitrust Developments, II2 U. PA. L. REv. 159, I6I-70 (1963).

372 U.S. at 261 . 
The case was remanded to the district court for trial, and eighteen months later a consent judgment was entered under which White, in essence, agreed to discontinue the restrictions on its franchisees' sales territories and customers. ${ }^{32}$ Thus, the impact of the entire proceeding on White's marketing activity was substantially the same as if the summary judgment had been upheld.

White Motor is among the roo largest industrial firms in the United States (ranking ninety-eighth in order of sales in Fortune's 1963 list) ${ }^{33}$ and among the ten largest firms engaged in production of motor vehicles and equipment, although it is less than one-fifth the size of Chrysler, the smallest of the big three auto producers, and less than one twenty-fifth the size of General Motors. It is, however, the largest firm specializing primarily in truck production, the next largest being Mack Truck. International Harvester is the other principal competitor in the relevant market. White is thus neither the dominant firm in its industry nor a pygmy newcomer engaged in a battle with the giants. In arguing that the case required a trial on its merits, White stated that its territorial restraints were necessary to the maintenance of its distribution network in competition with that of other manufacturers:

The plain fact is, as we expect to be able to show to the satisfaction of the Court at a trial of this case on the merits, that the outlawing of exclusive distributorships and dealerships in specified territories would reduce competition in the sale of motor trucks and not foster such competition. ${ }^{34}$

It also contended that its customer restrictions, which prohibited franchisees from soliciting business from governments and certain large accounts, were designed to permit White Motor sales representatives to deal directly with these accounts in competition with similar representatives from other truck manufacturers. The resale price restrictions were said to be ancillary, having as their purpose the maintenance of a particular discount structure for the various classes of accounts.

Leaving the price restrictions aside as per se violations whether or not they had any specific anticompetitive impact in this instance, it would appear that the conditions as set forth by White Motor would, if true, satisfy the standards for permissible customer-territorial restrictions presented in the body of this paper. The effects of the territorial restrictions in increasing the number of dealerships, extent of market coverage, and, therefore, the range of competitive alternatives in the covered markets, seem to have been clearly recognized by the Supreme Court and particularly by Mr. Justice Brennan in his concurrence. ${ }^{35}$ Justice Brennan, however, makes explicit objection to the customer reservations placed upon White franchisees, which we would defend. White's right to distribute all of its products through wholly-owned distribution outlets is unquestioned; however, Justice Brennan

\footnotetext{
${ }^{32}$ United States v. White Motor Co., 5 Trade Reg. Rep. (1964 Trade Cas.) If $71 \times 95$ (N.D. Ohio, Sept. 8, 1964$)$.

${ }^{33}$ Fortune, July 1964, p. 182.

${ }^{34}$ Quoted in 372 U.S. at 257.

so. Id. at $264-75$.
} 
accuses White of seeking "the best of both worlds-to retain a distribution system for the general run of its customers, while skimming off the cream of the trade for its own direct sales. That, it seems to me, the antitrust laws would not permit."3e The logic of this position is not evident. Although White's specific justifications for this practice may be criticized, the fact remains that neither in economic theory nor in law is there any particular connection between the extent of vertical integration and the strength of final market competition. The implication of Justice Brennan's position seems to be that customer reservation is in some way unfair to distributors, but how these distributors would be made better off by the elimination of their distributorships and the transference of all White's sales activities into vertically integrated outlets is not specified. By our standard, and on the basis of the limited information available, the White Motor distribution system, apart from its resale price restrictions, would have been permissible. ${ }^{37}$

\section{B. The Sandura Case ${ }^{38}$}

Sandura Co. is a relatively small producer ( 1962 sales of \$II million) of medium- to low-priced hard-surface vinyl floor coverings. It is engaged in competition with Armstrong Cork, Congoleum-Nairn, and Pabco, major producers of hardsurface floor coverings, and with a wide range of alternative products and floor treatments as well. The company's principal product, Sandran, is an inexpensive and easily installed vinyl produced by a patented rotogravure process, which was first placed on the market in 1949. After a rapid sales growth, the product revealed serious technical flaws, and sales deteriorated substantially as a result. After remedying these defects, the company again launched a program of expanded distribution. The expansion was accomplished under great financial restriction, due to the heavy losses on sales and repossessions of defective merchandise. Almost no funds were available for advertising, and, indeed, the distributors and retailers were expected to take on primary responsibility for sales promotion and merchandising. Sandura offered its distributors closed territories, within each of which the designated firm would have exclusive right to sell Sandura products to retail dealers, and limited retail competition by restricting the resale prices at which its products could be sold.

The Federal Trade Commission charged that the entire distributorship program constituted an unfair method of competition in violation of the Federal Trade Com-

\footnotetext{
${ }^{20}$ Id. at 274 .

${ }^{87}$ White's franchise agreements also included an exclusive dealership clause, such that each franchisee agreed not to handle competitive products. Although this clause was probably irrelevant with respect to the trucks themselves, it may have had some restrictive effect with respect to parts or accessories. These arrangements were explicitly not held to be per se illegal in the district court, and thus did not come to the attention of the Supreme Court; nor is this exclusive arrangement reached by the consent decree.

${ }^{88}$ Sandura Co. v. FTC, 339 F.2d 847 (6th Cir. 1964), affirming 6I F.T.C. 756 (1962). See also Stone, Closed Territorial Distribution: An Opening Question in the Sherman Act, 30 U. CHI. L. REv. 286 (1963).
} 
mission Act. $^{39}$ The hearing examiner found that the evidence failed to establish any injury to competition but held that the arrangement was illegal per se, and the Commission affirmed this view. ${ }^{40}$ The Commission's decision appears to rest importantly upon the view that the territorial arrangements were intrinsic elements in a retail price-fixing scheme that was per se illegal. On the appeal, however, the court of appeals pointed out that the dealer franchise plan establishing resale price maintenance antedated the territorial distribution system and did not appear to be directly connected with it. Thus, although the Commission was entirely justified in its findings with respect to price fixing, the court found that "closed territories made for the vigor and health of Sandura, increasing the competitive good that flows from interbrand competition without any showing of detriment to intrabrand competition." ${ }^{31}$ The court explicitly observed, with respect to the possible inference of horizontal conspiracy, that "no distributor is shown to have made unreasonable profits" and "the mere fact that distributors refuse to handle a product without closed territories is not sufficient basis for finding a horizontal conspiracy among them." In modifying the Commission's opinion, the court concluded that "this case is barren of credible evidence that the public would be benefited by requiring that Sandura distributors be allowed to intrude on each other's territory .... [O]n this record, the only justified conclusion is that elimination of the closed territory arrangement would impair competition, rather than foster it." ${ }^{\text {2 }}$

The conclusions of the court of appeals in this case are so clearly aligned with that of the preceding argument that further comment is not required..$^{43}$

\section{The Schwinn Case ${ }^{44}$}

Arnold, Schwinn \& Co. (Schwinn) is a family-owned corporation engaged in the manufacture of bicycles, parts, and accessories. It has one manufacturing plant in Chicago and accounted for 22.5 per cent of the United States bicycle market in I95I and 12.8 per cent in 196r. During that time, its marketing organization included distributors (wholesalers) and franchised retailers. Each of the former were allocated closed sales territories, and each of the latter was prohibited from purchasing from distributors outside the territory to which they were assigned. The enforcement of this arrangement was greatly facilitated by the "Schwinn Plan," under which distributors simply made sales contacts with retailers, who were then supplied directly from the factory. Distributors received a sales commission under this plan, which accounted for roughly one-half of Schwinn's sales. Consignment

\footnotetext{
${ }^{80} 38$ Stat. $7 I_{7}$ (I9r4), as amended, 15 U.S.C. $\$ \$ 4 \mathrm{r}-46,47-58$ (I964).

10339 F.2d at 855 .

1 Id. at 858 .

${ }^{2} \mathrm{Id}$. at $858-59$.

${ }^{4} \mathrm{~A}$ similar analysis and conclusion could be offered for the court of appeals decision in Snap-on-Tools Corp. v. FTC, 321 F.2d 825 (7th Cir. 1963).

"United States v. Arnold, Schwinn \& Co., 237 F. Supp. 323 (N.D. Ill. 1965).
} 
selling and bona fide agency arrangements were also used in some instances. Final retail sales prices were forcefully suggested by Schwinn. In $195^{8}$, the Department of Justice complained that these distribution arrangements, "all aspects of which are so completely interwoven and interinvolved as to constitute one, over-all, nationwide combination and conspiracy,"

The district court found no convincing evidence of price-fixing conspiracy. Further, the court noted strong similarity in the arrangements Schwinn had made with respect to franchised distribution and the intrafirm arrangements made by "its giant bicycle competitors, Sears, Roebuck and Co., and Montgomery Ward and Co."40 and found no fault with franchising as such. However, after an extensive review of the economics of bicycle distribution and Schwinn's own marketing analysis conducted over a period of years, the court found that, although "the general picture ... of territorialization-one distributor for a general area, and one retail dealer for a particular locality _ . . . is sound economically and perfectly legal," ${ }^{\prime 7}$ the pattern by which territories had been divided among distributors was essentially one of horizontal conspiracy. "Schwinn has a right to assign primary responsibility to a distributor in an area or territory" and the rights of a principal in any bona fide agency arrangement.

However, when a distributor fills orders from warehouse stock that he has purchased ... he is acting as an owner .... It matters not that no actual damage has been shown to any distributor or dealer. Such division of territory by agreement between distributors is horizontal in nature, and whether agreed upon after being imposed or even merely suggested from above ... by the manufacturer does not alter its illegality . ...48

It is difficult to distinguish the Schwinn arrangement, taken at face value, from that in Sandura or White Motor. However, it appears that a careful examination would reveal that the Schwinn arrangement is proscribed under our proposed standard. The crucial question is the first part of our two-part test: Does the arrangement increase market coverage over what it otherwise would be? From the findings of fact summarized in the opinion of the district court, there appears to be no problem in obtaining adequate market coverage for Schwinn cycles. On the contrary, it would appear that Schwinn is one of the leading producers of quality bicycles in the country, and its products are in demand throughout the distribution system. Thus, terriorialization does not appear to extend Schwinn's markets in any way but simply to reduce possible competitive contacts between Schwinn distributors and dealers. Whether this reduction in competition has any effect on profits we are not

\footnotetext{
"Id. at 326.

${ }^{10} \mathrm{Id}$. at 334 .

"Id. at 340 .

${ }^{48} I d$. at 342 .
} 
able to determine from the material available, but this issue is only secondary under the circumstances. ${ }^{49}$

\section{The Sealy Case ${ }^{50}$}

Sealy, Inc., is a patent and trade-mark holding corporation engaged in the business of licensing bedding manufacturers to produce and sell mattresses, foundations, and other bedding items under the Sealy name. Under the licensing agreements, manufacturers were restricted both as to their geographical sales areas for Sealylabeled products and as to their resale prices. The Department of Justice charged that these arrangements were per se illegal under section I of the Sherman Act. The district court accepted the Department's view with respect to the price-fixing arrangements, but upheld Sealy's contention that the territorial restrictions were "merely ancillary to ... several entirely legitimate business purposes . ..."

The history and internal organization of the Sealy organization are reviewed in some detail in the opinion, and that review cannot be repeated here. However, it is essential to note that the principal Sealy licensees were also stockholders and directors of the holding company. Thus, holding company decisions as to prices and territories were to a considerable extent horizontal agreements among some of the parties involved. Although parties to a particular territorial dispute were excluded from its final adjudication at the corporate level even when the parties were directors or members of the executive committee, the continuous interaction of licensees in the determination and realignment of territories is evident from the record. Sealy did not restrict its licensees from the production of bedding under their own or other labels, nor did the territorial restrictions apply to sales of such products; the effect of restrictive agreements in one product line on the manufacturers' policies with respect to others is not revealed in the material at hand.

It would appear that the Sealy arrangement would not be permissible under our proposed standard. It is true, as the court observed, that the history of Sealy shows a continuous expansion in the number of licensees and in the extent of market coverage. What the evidence does not appear to show, however, is that the territorial restriction contributed to this expansion, except insofar as it supported the price-fixing scheme. This may suggest that the territorial restraints, in themselves, are of negligible significance; indeed, the initial territorial limits appear to have been set in terms of break-even freight rate comparisons (i.e., "natural markets"). The "entirely legitimate business purposes" for which the territorial restraints were established and maintained, according to the court, were "royalty

\footnotetext{
10 The Schuinn case is a likely one for the substitution of quasi-integration, through agency agreements, for territorial restrictions; however, the restrictive arrangement cannot be defended on this ground alone.

${ }^{50}$ United States v. Sealy, Inc., 1964 Trade Cas. If 71258 (N.D. 1Il.), appeal docketed, 33 U.S.L. WEER 3404 (U.S. June 9, I965) (No. 238).

${ }^{82}$ Id. at 80073 .
} 
income ... and the benefits to licensees of joint purchasing, research, engineering, advertising and merchandising." ${ }^{32}$ However, nowhere in the opinion is the association made clear between these "purposes" and the restraints themselves, except in so far as the "purposes" were realized through the illegal price-fixing arrangement. Therefore, on the basis of the material available, it would appear that the territorial restrictions had, in fact, significance only as part of the over-all price-fixing conspiracy and have no justification for continued existence. The tolerance of the court for these restraints may, in fact, rest upon an assumption that, in the absence of the price-fixing arrangement, the ancillary restraints are purely formal. However, the possibility that these arrangements might serve as a substitute for the pricing agreement, or that they may otherwise restrain the behavior of the parties with respect to their own-brand products, suggests that the territorial restraints themselves may have significant anticompetitive impact.

\section{E. Concluding Comment}

The joining of territorial restrictions with price-fixing agreements in all of these cases, and in many other marketing arrangements as well, suggests the possibility of "guilt by association," and such associations no doubt lend support to extensions of per se rules of illegality to cover all restrictive marketing practices. However, the record to date is hardly conclusive. It may be that the continued accumulation of evidence will show that the great bulk of restrictive agreements fall within the Sealy-Schwinn format, in which territorial restraints do not appear to offer any expansion in the strength or scope of competitive forces. If so, a per se rule would be justified in terms of judicial clarity and managerial convenience. On the other hand, the White and Sandura evidence indicates that there are instances where, at a minimum, there is a strong presumption on the other side. This brief review of recent case material suggests the necessity for continuing detailed scrutiny of each case on its merits and the development of formal rules only after many more instances have been subjected to detailed examination. Although it can be easily argued that, as a matter of public policy, a minimum of restraints should be allowed on the working of the competitive enterprise economy, the concept of restraint must include not only limitations placed upon one private party by another but also limitations placed upon private parties by governments and courts.

\footnotetext{
is Id. at 80083 .
} 